\title{
What Role for the Law in Regulating Older People's Property and Financial Arrangements with Adult Children? The Case of Family Accommodation Arrangements
}

\author{
Teresa Somes and Eileen Webb
}

To some older people, the prospect of moving in with family to be 'cared for' as they age has considerable appeal. For example, an older person may choose to sell his or her home, invest the money in a child's property through the construction of a 'granny-flat' or extension and live in that property. If such arrangements are successful, the older person is likely to enjoy the companionship and support of family as he or she grows older. Unfortunately, the legal position of the older person if 'something goes wrong' is precarious. In the absence of a legislation addressing family accommodation or 'assets for care' arrangements written agreement, the older person must navigate the vagaries of several complex areas of law, particularly constructive trusts and estoppel, and endure the stress of proceeding against family members. This article discusses the shortcomings in the existing legal regimen and makes recommendations to provide legal protection for older people entering into such arrangements.

I stay too long by thee, I weary thee.

Dost thou so hunger for mine empty chair

That thou wilt needs invest thee with my honours

Before thy hour be ripe? O foolish youth! ${ }^{1}$

In Henry IV Part 2, Prince Hal, believing his father to have died, takes the crown from beside Henry IV and walks away, albeit to grieve. Upon waking and asking who has taken his crown, Henry IV chastises Hal for being so ready to grasp his inheritance, even before Henry's death. The scene resonates today: the unseemly haste of some children to inherit their parents' possessions. Indeed, unlike the admonished prince who was mistaken about his father's demise, it is not uncommon for family members to seek to enter into property arrangements and/or receive financial assistance while an older relative is still alive. Such arrangements effectively 'tap' into anticipated inheritances, generally known as inheritance impatience and may undermine an older person's housing and/or financial security. 
This article examines the role of the law in regulating a particular type of transaction between older people and their adult children: the 'Family Accommodation' or 'Assets for Care' arrangement. Its aim is modest; to provide an overview of the legal issues, and outline the relevant law that may be applied when an older party is seeking relief. This is in part a response to the fact that even if an older party seeks legal advice, many practitioners are unaware of the legal landscape to be traversed, in particular the often complicated matrix of equitable actions and remedies. Some conclusions for reform have been suggested, however further exploration of these reforms will be examined in more detail in a following article. In summary, it is concluded the existing Australian legal regime is inadequate to protect the rights of older persons who enter into property and financial arrangements with family members. Indeed, the status quo virtually guarantees that the older person will be deprived of their property - and financial security - in the event of such an arrangement breaking down. Law reform to protect the rights of older people with respect to these transactions is overdue and imperative.

\section{What is a Family Accommodation (or Assets For Care) Arrangement?}

Family accommodation arrangements, where older members of a family live on, or in, the same property as younger members, are increasing in popularity and in kind. Although there are many possible variations in the structure of these arrangements, their essence is that an older person's family receives a financial benefit in exchange for a promise to provide accommodation for, and in some cases care of, the older person as he or she ages. Such arrangements include accommodation 'solutions' that range from the purchase of a new home to accommodate the larger household; the archetypal 'granny flat' where an older member or members of a family live in a self-contained extension; a separate structure on a family member's property; the construction of an additional story or some other form of renovation on an existing home, or where the older person simply occupies a room in an existing house. Not all older people own their own home but can be subject to family accommodation arrangements through contributions of savings, investments and other assets. Of course, such accommodation arrangements are not entered into invariably with family members; in some cases such arrangements can be made with other relatives, friends or even acquaintances.

The legal framework regulating family accommodation arrangements is precarious. Despite the prevalence of 'assets for care' arrangements, and the recognition of the potential for exploitation of the older person, the law is uncertain and, from a practical perspective, largely ineffective. ${ }^{2}$ Most

2 Seniors Rights Victoria, Assets for care: a guide for lawyers to assist older clients at risk of elder abuse (2012) <http://www.seniorsrights.org.au/assetsforcare/ wp-content/uploads/Assets-for-Care.pdf>. 
such arrangements are informal and only come to light when something has gone wrong. When the arrangement breaks down - and assuming the older person has the financial and emotional fortitude to pursue the matter - he or she will encounter a situation that is difficult to settle or resolve. A dispute involving a family accommodation arrangement can give rise to a confusing amalgam of legal issues including, but not limited to, contract law, land law, equity, trusts and family law. There may be social security and/or taxation implications. The relevant law requires navigation of often contrary legal presumptions about the nature of family arrangements and joint endeavours. It is dominated by the vagaries of equitable doctrine and any relief is, for the most part, insufficient for the older person to 'start again'.

This article considers the law relating to family accommodation arrangements, as stated above. Although the article focuses on the Australian situation, the issue has implications elsewhere. As the population ages, and the cost of housing rises in most Western nations, more and more older people will make the decision to reside with family. Rather a broad assumption. Such decisions are likely to be predicated on aspirations of mutual benefit; an older person lives with their family for the rest of their lives while the child or children enjoy a financial injection through a contribution from the older person. Unfortunately, the legal regime is inadequate to protect the interests of the older adult where such an arrangement breaks down. Law reform to ensure the protection of older adults in such circumstances is overdue and imperative.

\section{Financial Abuse Through Family Accommodation ARrANGEMENTS}

The most prevalent kind of transaction involved in financial abuse is a disposal of land owned by the older person, or an investment in land without adequate protection, or for consideration which is illusory. These scenarios take many forms: a direct transfer of property to a child, using proceeds of the sale of a property to build a 'granny flat' at the back of a son's or daughter's property, use of sale proceeds to discharge the mortgage of a child's property or to buy another property in their name. A loose agreement to care for the older person is the usual accompaniment to these transactions. ${ }^{3}$

Statistics reveal that between two and five per cent of Australians over the age of 65 years have experienced abuse. ${ }^{4}$ Approximately 80 per cent of perpetrators are family members, usually children. ${ }^{5}$ The most common forms of abuse are financial and psychological abuse ${ }^{6}$ with older

$3 \quad$ Ibid, 9.

4 Wendy Lacey, 'Neglectful to the Point of Cruelty, Elder Abuse and the Rights of Older People in Australia' (2014) 36 Sydney Law Review 99, 100.

5 Ibid.

6 Mike Clare, Barbara Black Blundell and Joseph Clare, Examination of the Extent of Elder Abuse in Western Australia: A Qualitative and Quantitative Investigation 
women estimated to be twice as likely to be victims of abuse. ${ }^{7}$ Financial abuse can be perpetrated in many forms, however the risks for financial abuse of older people through 'financial loss arising from the disposal of an older person's assets in exchange for their future care and accommodation, often under pressure from another party' has increasingly become apparent. ${ }^{8}$ Indeed, since 2007 the majority of elder abuse cases dealt with by the Older Peoples Rights Service (OPRS) ${ }^{9}$ were financial and property related abuses. ${ }^{10}$ OPRS estimates 70 per cent of these matters involve family accommodation agreements. ${ }^{11}$

Before embarking on this discussion, it is important to state that many family accommodation arrangements are entered into and operate successfully. Families remain a primary source of support for older people and intergenerational living arrangements can and do provide financial and lifestyle benefits for families. ${ }^{12}$ Many such arrangements do not involve any financial motivation or expectation of 'something in return', either on the part of the older person or the family member. Even where an older child may benefit from financial assistance, and parents may want to contribute, society should not be quick to judge. As Hall has noted:

It is important to avoid stereotyping intergenerational relationships; the adult child who needs help is not by definition weak and grasping, nor is the older helper necessarily coerced, tricked or taken advantage of. ${ }^{13}$

Unfortunately, whatever the intentions and motivations for entering into a family accommodation arrangement, many are unsuccessful. The nature of our study necessitates a focus on the circumstances facing older persons when the arrangements fail.

of Existing Agency Policy, Service Responses and Recorded Data (Crime Research Centre, The University of Western Australia and Advocare Inc, 2011) 27-30 <http://www.law.uwa.edu.au/_data/assets/pdf_file/0008/2129606/2011-Examination-of-the-Extent-of-Elder-Abuse-in-Western-Australia.pdf $>$.

7 Lacey, above n 4, 100.

8 Seniors Rights Victoria, above n 2. Brian Kemp and Laura Mosqueda, 'Elder Financial Abuse: An evaluation framework and supporting evidence' (2005) 53(7) Journal of American Geriatric Society 1123.

9 Scott Johnson, Elder Abuse: The Need for Law Reform - Enduring Power of Attorney \& Family Agreements (2010) Older Peoples Rights Service <http://www. nsclegal.org.au/documents/EPOA_Report_2010_\%20April.pdf $>$.

10 Ibid, 15

11 The Older People's Rights Service (hereafter 'OPRS') in partnership with Advocare Inc (hereafter 'Advocare') has operated its specialist legal service as part of the services of our organisation, the Northern Suburbs Community Legal Centre Inc (hereafter 'NSCLC'), and in many situations the OPRS has witnessed older people losing their family home and/or life savings.

12 National Seniors Australia Productive Ageing Centre, It's not just about money: Intergenerational transfers of time and money to and from mature age Australians (2012) ii.

13 Margaret Isobel Hall, 'Equitable Fraud: Material Exploitation in Domestic Settings' (2006) 4 Elder Law Review 1. 


\section{An Overview of the Legal Hazards for Older People Entering Into Family Accommodation ArRANGEMENTS}

In most cases a family accommodation 'agreement' is not in the form of a contract; nothing has been written down and, in many cases, family members have differing recollections as to what the 'terms' of the arrangement are. While families could seek legal advice and enter into a formal family agreement, a prevailing attitude seems to be that solicitors are too expensive and that problems arise in other families.

Assuming the older person has capacity, ${ }^{14}$ there needs to be consideration of whether he or she entered into the agreement voluntarily, or as a result of some form of pressure. An older person, no matter how cognizant and capable of maintaining their own affairs, may be vulnerable to the persuasion of family or in the aftermath of a significant life event such as the loss of a spouse. If a property is transferred in such circumstances it is possible the agreement could be set aside by a court.

In circumstances where there has not been undue pressure on the older person such as any property transaction would be set aside; a court may intervene to ensure an older person does not lose all their investment or contribution. Therefore, where property has been transferred to or purchased for a child in the child's name or significant contributions have been made to the purchase price and/or contributions have been made to the joint household, complex questions will arise as to whether the transfer is a gift pursuant to a parent's concern for their child or was part of a joint enterprise. Perhaps a case or two! Depending on the structure of the arrangements, this can see the court consider a resulting trust (an implied trust in the amount of the gift or contribution), a constructive trust (arising through the common intention of the parties or because of the unconscionable nature of the arrangement) or an estoppel (where the older person has changed their position in reliance on the family members representations and it would be unconscionable to permit the family member to do so).

Finally, if land has become registered in the name of the child, whether through a transfer of the family home by the older person where the older person has sold his or her home and purchased outright or contributed to the purchase of land, the child is the registered proprietor and his or her their interest is indefeasible unless one of the exceptions to indefeasibility applies. ${ }^{15}$

14 A discussion of capacity is beyond the scope of this article. For present purposes it is sufficient to note that the law presumes that all adults have the necessary capacity to make important decisions, including entering into agreements or contracts unless there is evidence to the contrary: Borthwick v Carruthers (1787) 99 ER 1300 and Re Cumming (1852) 42 ER 660 at 668. The presumption has been given statutory force in the various Guardianship and Administration Acts throughout Australia where it is in force.

15 The most likely exceptions in this case are the fraud and in personam exceptions, although these can be very difficult to establish. 
Finally, a remedy may be problematic. The diversity of the arrangements may hard to predict how the arrangement will be classified and what remedy is available.

\section{Navigating the Relevant LaW And Judicial Process}

If the relationship between parties involved in 'assets for care' arrangements breaks down and the parties are unable to come to a mutually agreeable settlement, there may be no choice but to have the matter determined by a court. This alternative is far from ideal for a number of reasons.

First, resolving any dispute through litigation can be harrowing for those involved, and this is particularly so when the conflict is between parent and child. The parties therefore will need to have the financial resources and emotional resilience to cope with litigation. If money is tied up in the property itself, the older party will need to have independent financial resources.

Secondly, it is rare that those involved have fully anticipated the possibility of a breakdown in arrangements, and consequently have not made any provision in legal terms for the full protection of their interests. The lack of appreciation and planning for relationship breakdown is understandable within the family context, and has strong parallels with the pre-legislative de-facto property settlements of the 1970s. As Bryson J of the New South Wales Supreme Court has observed:

It is a sadly recurring judicial experience to see that family relationships do deteriorate and become intolerable, and that the persons involved did not foresee that this might happen. ${ }^{16}$

Indeed, the acknowledgement of a potential breakdown and the desire to seek legal advice may in itself be a source of conflict, as it could be interpreted as a lack of trust. Alternatively, if the property arrangement has been made because of the undue influence of the defendant, the older person may not feel empowered to secure their legal position prior to the arrangement being finalised.

Thirdly, court processes and reasoning derived from contractarian legal principles are often ill-equipped to deal with property arrangements that have as their foundation a mixture of familial duty, responsibility, care and security in one's old age and financial convenience. The law is competent in dealing with 'assets' but less so with 'care', and older people in these arrangements are at a risk of being worse off not only in a financial sense, but in the sense of losing security and support in their old age. As such the complex blend of motives behind these arrangements sits awkwardly with established legal principle and is difficult to value in monetary terms. 
An example of the difficulty is present in Bennett $v$ Horgan. In this case the plaintiff parents had loaned money to the defendants (their daughter and her husband) to purchase a property, and later sold their own property and built an extension on the defendant's house in the form of a self-contained flat for them to reside in until the death of the surviving parent. The defendants had experienced financial difficulty in the past and this was seen as a mutually beneficial arrangement for them to live in close proximity, and for the plaintiffs to help with bills and expenses. Apart from the charge over the initial amount lent, and a contractual licence to reside in the property, there were no provisions made conferring any proprietary interest in the property, the legal title being held entirely by the defendants. The relationship broke down, and the plaintiffs sought their initial charge, and a charge over the property to secure the money spent on the extension. In looking at alternative ways to calculate the sum owing, Bryson J observed that:

There are several possible ways of identifying the contribution made by the plaintiffs to the venture. To equate that contribution with the amount of money expended is not altogether satisfactory because the parties did not contemplate that the benefit would be closely related to the amount spent. Another way is to look to the increase in the value of the house produced by the expenditure. This too is not entirely satisfactory, as the contemplated venture the plaintiffs would never have enjoyed the value of the house in the sense of receiving part of its proceeds; they were to be advantaged only by residing in it. As they had this advantage until October 1990, the increase in value attributable to the improvements as of that date seems a better measure of the plaintiffs' contribution for the purpose of considering equitable remedies than the increase in value at the time when the works were completed. Even that however seems excessive as the contemplation was that the plaintiffs would have no more than enjoyment for their joint lives and the life of the survivor. ${ }^{17}$

The highlighted passages serve to demonstrate the inadequacy of legal reasoning in trying to reconcile monetary value with value derived by the plaintiffs from the residential arrangements. The conceptual principles of property, contract, and in some instances commercial law are inappropriate mechanisms to resolve disputes in a family context. ${ }^{18}$ In particular, the attempt to equate the increase in value of the property from the date the plaintiffs had left with the enjoyment of the plaintiffs of the property for their joint lives appears unsatisfactory.

The reason for this lies largely with the nature of our legal system, which is very much 'rights based'. In most 'assets for care' arrangements, legal title to the property is held by the defendant, and the common law does not recognise claims over the property by the plaintiff pursuant to informal arrangements, improvements to property in the form

17 Ibid, [17] (emphasis added).

18 For a discussion of the conflict in applying commercial law principles in the context of older persons acting as guarantors to family members, see Juliet Cummins, 'Relationship Debt and the Aged: Welfare vs Commerce in the Law of Guarantees' (2002) 27(2) Alternative Law Journal 63. 
of renovations, additions or extensions which have been undertaken in exchange for residency and care. Therefore, a plaintiff must look to equitable principles for relief. The equitable jurisdiction evolved as a body of rules to mitigate against the harshness of the common law, ${ }^{19}$ and certainly equitable principles allow plaintiffs to gain relief through the principles of unconscionability, estoppel and undue influence, however, the establishment of the cause of action is still firmly based in the establishment of a 'right', and the assessment of the award invariably flows from that right. This rights based approach fails to take into account other methods of assessment, for instance assessment based or influenced by whether the plaintiff deserves to have an interest in the property by virtue of their actions, or whether what the needs of the respective parties may be. In many ways this is a particular shortcoming of the present approach, and potentially disadvantages the older party. Although a needs assessment may indirectly have some bearing in the calculation of the final remedy, they are not primary concerns driving the decision-making process.

The remedies available to an older party in an assets for care dispute will depend to a large extent on the initial cause of action, which in turn is dictated by the particular circumstances and between the parties giving rise to the dispute. However, the claimant may claim relief on several bases: the same fact situation may give rise to a number of potential causes of action, therefore it is advisable to consider from the outset the relief the party wishes to obtain, as that will act as a guide to the most appropriate cause of action to plead. ${ }^{20}$ For example, in Sleboda $v$ Sleboda,${ }^{21}$ the claimant alleged unconscionable conduct and undue influence, and could also have argued relief should be granted on the basis of a resulting trust. Further, it is to be remembered that equitable remedies are discretionary, and the court, although guided by 'principle and precedent', will strive to determine the most appropriate remedy available. Therefore, a combination of remedies may be appropriate, and matters such as awards for costs or compound interest may be a way of tailoring an award. The structure of this section will be to outline the main causes of action available, and the common remedies awarded for a successful action. Each remedy will then be examined in more detail in order to explain its operation.

\section{Potential Causes of Action}

\section{A Fraudulent or Unconscionable Denial of Benefit}

An agreement between parties that an older person will be able to reside at a property pursuant to a life interest in the property will not be recognised

19 Dudley v Dudley (1705) 24 ER 118, 119 (Lord Cowper).

20 A claimant is permitted by the relevant Supreme Court Rules in each State to plead a number of causes of action in addition to one another, therefore you may plead a number of causes of action in the one pleading. [2007] NSWSC 361. 

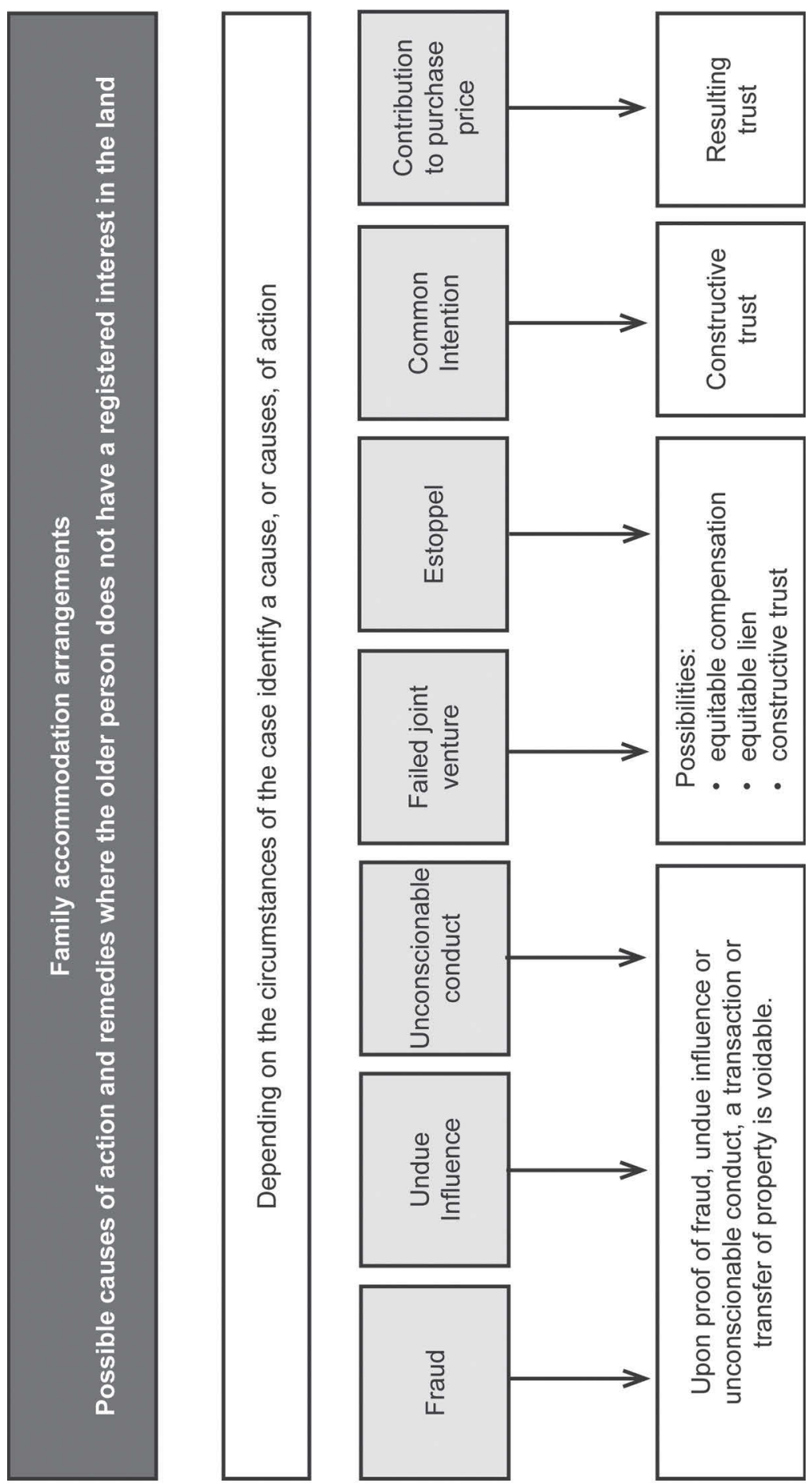
at common law unless the agreement is in writing. ${ }^{22}$ Although provision is made in the relevant legislation that a lack of writing may give rise to a tenancy at will, this will not be of benefit to the elder party as the tenancy can be revoked, and the elder party may be evicted. In these circumstances equity may prevent the defendant's unconscionable reliance on the statutory requirement of writing and the denial of the tenancy. In Jones $v$ Jones, ${ }^{23}$ a 79 -year-old woman had sold her property and paid her son $\$ 100,000$ on the understanding she was to live in a property owned by him for the remainder of her life, and look after her granddaughter. The money was not used to purchase the property, but was used by the son to pay outstanding debts. The arrangement continued for a number of years, until the granddaughter moved out. The son then issued his mother with a 'Notice to Leave', and subsequently sold the property. Although he undertook to pay her $\$ 20,000$ to assist in relocation expenses and payment of $\$ 140$ per week, neither of these undertakings were honoured. The court found that despite the absence of writing, the undertaking by the son that his mother would be entitled to a life tenancy or an interest in the property was sufficient to recognise a constructive trust over the property, to relieve against the equitable fraud in not honouring the obligation. Reliance was placed on the English case of Bannister $v$ Bannister,${ }^{24}$ whereby a defendant had sold a cottage to a plaintiff at an undervalue on the understanding that the defendant would live in the property for as long as she wished. The plaintiff subsequently attempted to evict the plaintiff in order to sell the property with vacant possession. The court found that the plaintiff held the property on constructive trust for the defendant for life. Similarly, in Jones $v$ Jones, ${ }^{25}$ the court found a constructive trust arose in favour of the mother, however as the property had been sold, the court substituted an amount of equitable compensation based on the plaintiff's loss of an ongoing right of life tenancy, from the date she was required to vacate the premises. That amount was calculated at $\$ 164,595$, with compound interest. Had the property not been sold, the available remedies may have ranged from a licence to reside in the property for life, ${ }^{26}$ a constructive trust of a life interest (as was held in Bannister $v$ Bannister) or a constructive trust over the whole property.

\section{B Unconscionable Conduct}

The doctrine of unconscionable conduct is another example of equity intervening in transactions on proof of specific fraudulent conduct ${ }^{27}$ of

22 Conveyancing Act 1919 (NSW) s 23(1); Property Law Act 1974 (Qld) s 11(1); Property Law Act 1969 (WA) ss 34, 53; Property Law Act 1958 (Vic); Law of Property Act 1936 (SA) s 29; Conveyancing and Law of Property Act 1884 (Tas) s 60.

23 [2014] QDC 150.

24 [1948] 2 All ER 133.

25 [2014] QDC 150.

26 But note the concerns of the court in Pascoe $v$ Turner [1979] 1 WLR 431.

27 'Fraud' in equity has a much broader meaning than at common law. It need not amount to actual dishonesty, but when [the conduct] 'appears to a judicial 
the defendant. An older party relying on the doctrine of unconscionable conduct would be claiming relief where there has been an 'abuse of power possessed by one party over the other by virtue of the other's position of special disadvantage', ${ }^{28}$ and where there has been 'the unconscientious attempt to retain the benefit obtained from the person with the special disadvantage'. ${ }^{29}$ The crucial element to establishing this cause of action is the proof that the party relying on it is suffering a 'special disability'. The doctrine is not concerned with the unfairness of the contract, but is aimed at preventing the stronger party knowingly taking unconscionable advantage of the disability. 'Special disability' may refer to the specific characteristics of the weaker party, such as sickness, age, infirmity of body or mind, drunkenness, illiteracy or lack of education, lack of assistance or explanation where assistance or explanation is necessary. ${ }^{30}$

Alternatively, a special disadvantage may arise owing to the particular nature of the relationship between the parties, such as an emotional dependence. ${ }^{31}$ In either case, the special disability must seriously affect the disabled party's capacity to judge or protect their own interests. In Bridgewater $v$ Leahy, it was noted that the equity to set aside the transaction 'may be enlivened not only by the active pursuit of a benefit it conferred but by the passive acceptance of that benefit'. ${ }^{32}$ Where the weaker party has established they were suffering a 'special disability', the onus falls on the stronger party to establish that the transaction was 'fair, just and reasonable'. ${ }^{33}$ Evidence such as adequacy of consideration or the weaker party's receipt of independent legal advice may indicate the transaction was not unconscionable.

The remedies available under this doctrine will depend on the nature of the transaction entered into, but generally the court will order the setting aside of any contract entered into, or the rescission of a voluntary transaction. This could take the form of an order to transfer property from the stronger party to the weaker party or that the property should be held on trust.

For instance, in Sleboda $v$ Sleboda,${ }^{34}$ the plaintiff bought a farming property with his son. Criminal charges were pending against the son, and the property was conveyed to the father. At a later date, the father signed documents understanding they were to transfer the property to himself and his son as tenants in common in equal shares, whereas in fact

conscience as being so unconscientious that it should not be allowed to stand': Logue v Shoalhaven Shire Council [1979] 1 NSWLR 537, 555.

28 Australian Competition and Consumer Commission v Radio Rentals Ltd (2005) 146 FCR 292, 297.

29 Johnson $v$ Smith [2010] NSWCA 306, [5].

30 Blomley $v$ Ryan (1956) 99 CLR 362, 405.

31 For example, Louth v Diprose (1992) 175 CLR 621, where the weaker party was said to be 'romantically infatuated', and knowledge of this was used to manipulate the weaker party.

32 (1998) 194 CLR 457, 493.

33 Commercial Bank of Australia v Amadio (1983) 151 CLR 447, 475 (Deane J).

34 [2007] NSWSC 361. 
he had transferred the whole property back to his son. A dispute arose between the parties, and the son asserted his legal title over the whole property. Evidence suggested that the father had in fact contributed to more than half of the value of the property, which under resulting trust principles may have entitled him to an order that his son hold the property on trust in shares proportionate to the respective contributions. Rather, he sought orders declaring the property be held on constructive trust for the father and son in equal shares, as tenants in common on the basis that that the transfer was a consequence of the son's unconscionable conduct, and undue influence. Both causes of action were proven on the evidence. Josef Sleboda suffered a special disadvantage owing to his ill-health, partial deafness and poor English. Gzell J found that the father's special disability:

led him to place complete trust in his son and, so doing, he was in such a disadvantageous position as made it unconscionable for Mr John Sleboda to rely on that trust in asking his father to sign the documents without them being read to him or explained to him..$^{35}$

Gzell $J$ found in favour of the father, and declared the son held one half of the property on trust for his father as tenants in common in equal shares. ${ }^{36}$ The finding of a trust however does not impose upon the trustee management responsibilities equivalent to those under an express trust. The trust is merely a declaration of entitlement, and the trustee is then ordered to execute documents to transfer the share to the beneficiary. ${ }^{37} \mathrm{Had}$ the son dealt with the property or sold the property, then his father would have both personal and proprietary remedies available to him against his son, for restitution of the property or its value.

\section{Undue Influence}

Undue influence is a similar, yet distinct doctrine from unconscionable conduct. Whilst unconscionable conduct looks at the conduct of the stronger party, undue influence looks at the quality of the assent of the weaker party, and a transaction or voluntary conveyance can be set aside if the consent given by the weaker party was made pursuant to the relationship of influence. ${ }^{38}$ Elderly people may be placed in a vulnerable position when they become dependent on others, and that relationship of dependency has the potential to be misused. As such the doctrine of undue influence appears to be a powerful safeguard against such exploitation. However, the onus placed on the older party of proving the transaction was a result of undue influence is onerous, ${ }^{39}$ and there have been very few instances

$35 \quad$ Ibid, [53].

36 An appeal from this decision to the Court of Appeal was dismissed: Sleboda $v$ Sleboda [2008] NSWCA 122.

$37 \quad$ See Giumelli v Giumelli (1999) 196 CLR 101, [5].

38 Commercial Bank of Australia v Amadio (1983) 151 CLR 447, 474.

39 Certain relationships give rise to a presumption of undue influence: solicitor/ client, doctor/patient, trustee/beneficiary and parent/child, although in the latter 
of success. ${ }^{40}$ If however the relationship is found to be one of influence, a transaction will be set aside unless it can be proven that the older party was acting independently, and entered the transaction.

The recent case of Janson $v$ Janson $^{41}$ is an example of a successful claim of undue influence. In this case an elderly (92-year-old) deaf, almost blind, childless bachelor gifted his interest in a house to his nephew. The house, valued at $\$ 660,000$, was his only asset, and was owned by him and his two younger brothers in equal shares as tenants in common. The nephew had looked after the claimant and a power of attorney had been executed whilst the claimant was hospitalised. The claimant had subsequently signed the transfer articles but was clearly confused about the nature of the documents. No independent legal advice was given to the claimant. The court observed that:

No independent solicitor or other professional person was present when the transfer was executed. The only relatively independent person whom Eric saw was Ms Benson, who was present to witness his signature. She was not entirely independent because she had a family bond with Richard through her friendship with his father which brought about her attendance .... There was no advice as to whether he should enter into the transaction at all, the propriety of the transaction or discussing alternative means of arranging his affairs. Nor was Ms Benson an independent solicitor, or someone in a similar professional position. ${ }^{42}$

The court found that the claimant had not signed the transfer by virtue of his free will, although he had repeatedly stated he wanted his nephew to have the property when he died. The court found that the claimant fell within the category of presumed undue influence, in that he reposed trust and confidence in his nephew, and the nephew was in a position of influence owing to that trust and confidence. As such the transfer was set aside.

Despite the above cases, in the context of assets for care situations, pleading unconscionable conduct and undue influence is relatively uncommon. This is because in most instances the parties have entered into the arrangement voluntarily, anticipating that the arrangement will be for their mutual benefit. By contrast, where both unconscionable conduct and undue influence is alleged, the doctrines assume that the arrangement was tainted from the outset. Consequently, the cause of action predominately relied upon is the failed joint venture under the Muschinski $v$ Dodds ${ }^{43}$ principles.

case the presumption is in favour of the child. There is no presumption of undue influence of a child over the parent. Therefore, the parent has the onus of proving as a matter of fact that the relationship was one where the child was in a position of influence over the parent.

40 Fiona Burns, 'Undue influence Intervivos and the Elderly' (2002) 26(3) Melbourne University Law Review 499.

41 [2007] NSWSC 1344.

42 Ibid, [106].

43 (1985) 160 CLR 583: these principles are aimed at preventing the unconscionable retention of benefit, or a 'windfall', where payment is made pursuant to a planned 


\section{Estoppel}

The general nature of estoppel was explained by Lord Cranworth in West $v$ Jones: ${ }^{44}$

Where a party has by words or conduct, made a representation to another leading him to believe in the existence of a particular fact or state of facts, and that other person has acted on the faith of such representation, then the party who made the representation shall not afterwards be heard to say that the facts were not as he represented them to be.

In the context of assets for care situations, estoppel may be argued where an owner of property encourages an older party to alter their position, either by expending money on property, improving or building on property, in the expectation that the elder party will obtain a proprietary interest. To successfully make out an estoppel claim, the claimant must establish that there was a representation made by the defendant which created an expectation in the claimant and as such relied on that representation to their detriment, and the defendant knew of this reliance. ${ }^{45}$ It has been suggested that there is less reliance on this doctrine that the failed joint venture' doctrine, owing to the difficulty in proving reliance by the claimant on an assumption created or encouraged by the defendant. ${ }^{46}$ This may well be true, as the particular elements of the cause of action must be proven, and in the context of the family, either the criteria regarding the scope of the arrangement is not explicitly expressed, or there is vastly conflicting evidence amongst family members as to expressions of intention and entitlement. One concern, however, expressed by the authors is the different criteria applied in relation to the remedy available. In estoppel cases, the possibility that the expectation of the claimant can be realised through the available remedies contrasts with the criteria for calculating the remedy in 'joint venture' cases. Therefore, in estoppel cases:

There is no governing principle that requires that the relief granted be that which is the minimum necessary to do justice. To the extent that there is a prima facie entitlement to relief on the basis that the adopted expectation is to be made good, that entitlement must be weighed against any injustice to the estopped party in doing so and the detriment suffered by the party who has acted upon the induced expectation. Consideration should be given to whether the proposed relief has any adverse effects on the interests of third parties. ${ }^{47}$

In contrast, the 'joint venture' cases:

joint venture, and the substratum of that joint venture is removed without attributable blame such that the venture is not seen through to its conclusion.

44 (1851) 61 ER 79.

45 Giumelli v Giumelli (1999) 196 CLR 101; Delaforce v Simpson-Cook [2010] NSWCA 84.

46 Susan Barkehall Thomas, 'Families Behaving Badly: What happens when grandma gets kicked out of the granny flat?' (2008) 15(2) Australian Property Law Journal 154, 165.

$47 \quad$ Walsh $v$ Walsh [2012] NSWCA 57. 
$[O]$ ne looks not to the detriment that might be suffered because the arrangement did not continue, but merely to the detriment of losing a fund to the other party to the arrangement through unexpected circumstances, where such a loss would result in the either having an unconscionable gain. ${ }^{48}$

This is based on the reasoning that in the joint venture cases the promise has been fulfilled (in that the living arrangements have been organised, but the arrangement has broken down), whereas in estoppel cases the promise has not been fulfilled. The distinction highlights the artificiality of the rights-based approach to such arrangements, and the dangers of drawing analogies with commercial enterprises. The aim of the joint venture approach is to prevent one party gaining a 'windfall', but does nothing to anticipate loss that is experienced by the elder party in relation to their long-term care and security.

A very straightforward example of the application of estoppel principles is found in the recent case of Pobjoy $v$ Reynolds. ${ }^{49}$ In this case the plaintiff, a 79-year-old pensioner, brought an action against her daughter (the first defendant) and her son-in-law (the second defendant) claiming she agreed to sell her property on the understanding that the proceeds would be applied to a new property which the defendants would purchase in their name, and the new property would either have a granny flat or one would be constructed for her. She agreed to contribute to the utilities and the defendant agreed to care for her. A total of $\$ 121,437.80$ was provided by the plaintiff to the defendants. Relationships between the mother and daughter, and the daughter and her husband, deteriorated, and the parties moved out. The property was to be sold pursuant to family court orders. The court found that:

The plaintiff was encouraged by the first defendant to contribute to the property on the representation made by, and an expectation created by, the first defendant, that the plaintiff would be entitled to reside there. The first defendant now seeks unconscientiously to depart from the representation and to deny the plaintiff fulfillment of the expectation which she created, and upon which the plaintiff acted to her detriment. In these circumstances, the Court will compel the first defendant to give effect to the expectation. ${ }^{50}$

Therefore, in the present case, the court imposed a charge over the first defendant's interest in the property in favour of the plaintiff. The second defendant successfully argued he was not party to the arrangements.

In such cases, the court will strive to find the most appropriate remedy. In Sidhu $v$ Van Dyke,$^{51}$ the High Court of Australia noted that 'the real detriment or harm from which the law seeks to give protection is that which would flow from the change of position if the assumption were deserted that led to it'. Whilst there has been tension in discerning which circumstances require the 'minimum equity' approach as opposed

$48 \quad$ Henderson $v$ Miles (No 2) [2005] NSWSC 867, [95].

49 [2013] NSWSC 885.

50 Ibid, [13].

51 [2014] HCA 19, [79], citing Waltons Stores (Interstate) Ltd v Maher [1988] HCA 7 (Brennan J). 
to fulfilling the plaintiff's expectation loss, the High Court found that in cases where the detriment suffered was 'of a kind and extent that involve[d] life-changing decisions with irreversible consequences of a profoundly personal nature, ${ }^{52}$ in contrast with detriment that amounted to 'a relatively small, readily quantifiable monetary outlay', ${ }^{53}$ then the appropriate measure of relief was the value of fulfillment of the appellant's promises. In the context of assets for care disputes, this supports the view that an estoppel claim may be a more attractive option for the older party, however it remains to be seen exactly how the courts will assess the notion of the 'value' of the fulfillment of the promise.

\section{E Failed Joint Venture}

By and large assets for care situations are resolved relying on the concept of the 'failed joint endeavour' principle. This principle, which is derived from the landmark case of Muschinski v Dodds, states that:

[T] he principle operates in a case where the substratum of a joint relationship or endeavour is removed without attributable blame and where the benefit of money or other property contributed by one party on the basis and for the purposes of the relationship or endeavour would otherwise be enjoyed by the other party in circumstances in which it was not specifically intended or specially provided that that other party should so enjoy it. The content of the principle is that, in such a case, equity will not permit that other party to assert or retain the benefit of the relevant property to the extent that it would be unconscionable for him so to do'. ${ }^{54}$

As noted above, the court's approach to applying a remedy in the joint venture situations has commonly been to apply the 'minimum equity' approach to prevent the party holding the legal title from gaining a windfall, rather than to compensate the elder party for their loss of expectation. The outcome is often the property is held on constructive trust in proportion to the party's contributions. This outcome, however, potentially fails to recognise the foundations on which the arrangement was entered into, in that there is often an assurance of care and security provided for the elder party, although it does recognise that the elder party has a beneficial interest in the property through the imposition of a constructive trust. The advantages of an order of a constructive trust are explained below. The emphasis is thus the prevention of an unconscionable retention of property, rather than the loss or detriment suffered by the elder party. Hence, in Bennett $v$ Horgan, Bryson J said:

Prima facie the plaintiff's entitlement is to a proportionate repayment of their capital contribution on the premature collapse of the venture, but the true remedy is such order as will prevent the defendants from retaining the benefit of the property to the extent that it would be unconscionable for them to retain it. ${ }^{55}$

52 Ibid, [84] citing Donis v Donis (2007) 19 VR 577 [34] (Nettle J).

53 [2014] HCA 19, [84].

54 (1985) 160 CLR 583 (Deane J) (emphasis original).

$55 \quad$ [1994] NSWSC 91. 
A constructive trust based on respective contributions to a failed joint venture was applied in Swettenham $v$ Wild $^{56}$ and McKay $v$ McKay. ${ }^{57}$ In the latter case, the defendant and his de-facto wife (B) were the owners of a property as tenants in common in equal shares. The defendant became ill, and the de-facto relationship broke down. It was proposed that his daughter and her partner, the plaintiffs, buy out B's share of the property, and the defendant assign his share of the property to his daughter in exchange for an entitlement to reside in the property, and care for the remainder of his life. The agreement was recorded by deed. The arrangement continued for a time, whereby the relationship broke down and the plaintiffs moved out. The plaintiffs claimed they were entitled to the whole property subject to an obligation to pay the defendant the value of his lifetime right of residence. As the agreement was by deed, they contended that the dispute was contractual, and the liability was only to pay damages. The defendant claimed it was unconscionable for the plaintiffs to retain the benefit of the transfer in circumstances that had not been intended, and as such the substratum of the relationship on which the transfer of the proper interest was undertaken had been destroyed.

The court found that owing to the nature of the relationship, the elements of mutual trust and confidence, the obligations to provide care and the fact that the arrangement was in a family context, that this was not merely a contractual arrangement. The final order reflected the respective contributions: the property was to be sold by trustees ${ }^{58}$ the plaintiffs to pay the balance of the mortgage, and the defendant to pay the plaintiffs an occupation fee for the period the defendant resided in the property after the plaintiffs moved out.

In Langford $v$ Redd $y^{59}$ the claimant transferred her property to her daughter and her son-in-law, on the understanding they would build a granny flat for her. Alleging undue influence and unconscionable conduct, the claimant argued she was tricked into transferring her property to the defendant. Although the grounds of undue influence and unconscionability were not found, the claimant was still entitled to an equitable life interest in the property on the basis of the failure of the consensual joint endeavour. The court declared a constructive trust of a life estate in the property in favour of the plaintiff.

56 [2005] QCA 264. Although the court made a declaration that the respondent held her legal ownership of the property on constructive trust, giving the appellant a proportionate share in the property, the appellant only sought repayment of his original contribution together with interest, and the final award reflected that amount.

58 Although not specifically mentioned, it is implied that, before the sale, the plaintiffs held the property on trust for themselves and the defendant in equal shares, the final accounting being subject to the orders made in relation to the mortgage and occupation fee. 


\section{F Contributions to Purchase Price}

Unequal contributions to the purchase price that are not reflected in the legal title may lead the court to declare the property is held on resulting trust. Resulting trusts are based on the presumed intentions of the parties; a court will give effect to the grantor's intention by adopting a presumption in regard to that intention. ${ }^{60}$ They may arise in a number of situations, including where property is purchased by one party, but held in the name of another party; where property is purchased jointly and is only in the name of one party; or where property is held jointly, but the respective contributions to the purchase price were not equal.

An older person who contributes money towards the purchase of a property (or payments towards a mortgage), and this is not reflected on the title, may claim that the property is held on resulting trust for them in proportion to their contributions. However, there are a number of obstacles that may either prevent a resulting trust arising, or determine that the resulting trust is an inappropriate remedy.

First, the contribution must be towards the property itself. Payments made must be directly referable to the purchase price, and not towards any other purpose. ${ }^{61}$ Therefore, money contributions towards mortgage instalments made after the purchase will not be treated as contributions to the purchase price, ${ }^{62}$ nor will money paid towards renovations or extensions. The latter may only give rise to a trust if there is a common intention or agreement between the parties, or where the facts give rise to an estoppel.

Secondly, the court will look to the intention of the parties at the time of purchase. In many cases, the older party intends that the property be held by the child, in exchange for accommodation and care. In circumstance the presumption of resulting trust will be rebutted by evidence of contrary intention. ${ }^{63}$

Thirdly, the contribution may be determined to be a gift. In certain relationships equity will assume the purchase or contribution has been made by way of gift, rather than presume a resulting trust. Transfers or contributions made from husband to wife or parent to child, are presumed to be gifts by way of advancement. The underlying justification is that parents will strive to enable their children to become independent. As such, an older party would have to rebut the presumption of advancement to allow a resulting trust over money paid towards the purchase price of a property in their child's name.

Hence a resulting trust will only take into account very narrow criteria, and although may secure initial money contributions, will not take into account the wider circumstances and contributions made by a party.

$60 \quad$ Calverley v Green (1984) 155 CLR 242, 246, 266.

61 Haley $v$ Perkins [2010] NSWSC 1091, [78].

62 Tabtill Pty Ltd v Creswick [2011] QCA 381, [159].

63 See, eg, Anderson v McPherson (No 2) [2012] WASC 19. 


\section{G Common intention to share property}

A trust may be imposed over the property in circumstances where it can be established that the parties expressed a common intention to share the property.$^{64}$ There must be evidence of the actual intention of the parties, rather than inferring what fair and reasonable persons in the exposition of the parties would have intended. ${ }^{65}$ The common intention constructive trust is of limited value in assets for care situations. The onus is on the party alleging there was a common intention to adduce evidence that there was a mutual intuition to share the proprietary interest in the property. This may not always be the case as the older party may not have envisaged or intended obtaining a proprietary interest. In many cases the intention is that the interest lie solely with the child, as the mutual arrangement benefits the financial position of the younger party, in return for the benefits of care and accommodation for the rest of the older party's life. If a common intention constructive trust is imposed, the quantum of interest held by each party will reflect their intentions, otherwise the court will determine what best gives effect to those intentions.

\section{Remedies Available on Proof of the Cause of Action}

Although appropriate remedies have been explored to some extent under the respective causes of action, the following is a summary of the purpose of the primary remedies that are available. It is to be noted that the remedies in equity are discretionary, and the courts will strive, within the confines of equitable doctrine, to determine the most appropriate remedy, whilst achieving a degree of practical justice. Therefore, a combination of orders may be appropriate.

\section{A Setting Aside Transfer, Order to Re-Convey Property to Claimant}

In circumstances where a transaction or transfer has been procured by undue influence or unconscionable conduct, the court may order the transaction is to be set aside and property transferred back to the claimant.

\section{B Equitable Charge - Over Proceeds of Sale}

In Terry $v$ O'Connell ${ }^{66}$ a mother spent $\$ 60,000$ converting a garage on her daughter's property into a granny flat in return for being able to stay in the property free of charge. In discussions with her daughter, she agreed that if the property was sold, she would accept $\$ 40,000$. The relationship broke down and the property was eventually sold. The plaintiff claimed an interest in the property in the nature of an equitable charge or equitable

$64 \quad$ Jin v Yang [2008] NSWSC 754.

65 Shephard v Doolan [2005] NSWSC 42, [34].

66 [2010] NSWSC 255. 
mortgage in the sum of $\$ 40,000$. The court found that the plaintiff did not have a charge over the property, but rather a charge over the proceeds of sale. An interest in the proceeds of sale is not an interest in the land, in that the chargee of the proceeds of sale does not have a right to have the land sold.

\section{Equitable Lien}

An equitable lien and charge are similar concepts, although the charge is generally considered to arise through agreement between parties, and a lien is a remedy imposed by the court.

An equitable lien is thus a charge imposed by equity against property that renders the property security for an obligation owed to the plaintiff by the defendant. It is commonly called a secured equitable charge, and is enforceable against a third party who is not a bona fide purchaser with notice of the security.

The purpose of the equitable lien is to give to the claimant a security interest in the property that will obtain priority but does not entitle the claimant to possession, use or ownership of the property. As such the payment can be made to satisfy the lien without having to sell the property. In an assets for care situation this quality makes the lien a valuable remedy, as the defendant may be able to satisfy the equity without selling the family home.

A lien may be a preferable remedy if the value of the property has depreciated. Unlike a constructive trust, the equitable lien does not give the licensee a beneficial interest in the property. Conversely, if the property has appreciated, the beneficial proprietary right under the trust will include any increases in value.

In Stoklasa $v$ Stoklasa,${ }^{67}$ the defendant had a house transferred to him at an under-value on the basis that he would care for the plaintiff. The relationship subsequently broke down. Gzell J found:

It would be unconscionable and inequitable for [the defendant] to retain the benefit of the transfer of the house at an under-value freed from the obligation of providing care and accommodation.

In those circumstances it was considered appropriate to grant an equitable charge for the value of the obligation. There had been no expenditure by the plaintiff, but he had caused the defendant to have the house at an under-value. Although it was determined that it was not unconscionable for the defendant to retain the benefit of the transfer at an under-value, the appropriate remedy was to grant a charge for the value of the extra benefit that the defendant had gained.

\section{Constructive Trust}

A constructive trust may be imposed, irrespective of the parties' intentions, in cases where there is a dispute over the beneficial entitlement 
to property. It can be imposed by the courts in circumstances where it would be unconscionable for the legal titleholder to assert or retain the benefit of property. Unlike express trusts, the constructive trust does not impose ongoing trustee duties on the trustee, rather the obligation is to disgorge the entrusted property and deliver up the trust property to the beneficiaries. It is most commonly imposed in cases of estoppel or failed joint ventures, or where a common intention to share the property has been found.

The touchstone of the constructive trust is the prevention of unconscionable conduct. Deane J in Muschinski v Dodds stated that:

Notions of what is fair and just are relevant but only in the confined context of determining whether conduct should, by reference to legitimate processes of legal reasoning, be characterized as unconscionable for the purposes of a specific principle of equity whose rationale and operation is to prevent wrongful and undue advantage being taken by one party of a benefit derived at the expense of the other party in the special circumstances of the unforeseen and premature collapse of a joint relationship or endeavour. ${ }^{68}$

The imposition of a constructive trust has certain advantages for the claimant. First, it gives the claimant an equitable proprietary right in the property, which is enforceable against all but the bona fide purchaser for value without notice. If the owners of the property were to be declared bankrupt, the beneficial title held by the beneficiary would be immune from being included in the assets for distribution. Secondly, the constructive trust allows for the beneficiary to take advantage of any increase in the value of the property. Thirdly, it may be easier to impose a constructive trust over specific property rather than calculate a specific monetary award.

In Peterson $v$ Hottes $^{69}$ the appellant provided $\$ 70,911$ to her daughter (the respondent) to assist in her purchase of a residential property. The parties contemplated that the appellant would live at the property with the respondent; this was the case until the relationship broke down irretrievably and the appellant left the property.

The appellant commenced proceedings claiming a beneficial interest in the property. The court found that presumption of advancement which arose by reason of relationship between parties had been rebutted by evidence including evidence of the appellant's intention, known to the respondent, to make payment in order to secure continuing arrangement to reside with her.

The court held that an order to repay the sum of money contributed was insufficient to address the respondent's unconscionability in the circumstances of the case. It was held it would be unconscionable for the respondent to retain full title to and benefit of the property and it was appropriate to declare that respondent held property in trust beneficially as to 25 per cent for appellant and 75 per cent for respondent.

68 (1985) 160 CLR 583 (Deane J).

69 [2012] QCA 292. 
A constructive trust may be imposed, however, if the property is no longer extant, the court may substitute compensation in lieu of the constructive trust. This was the order made in the case of Jones $v$ Jones. $^{70}$

In determining the scope of the constructive trust, the court may consider both direct and indirect contributions to the property, as well as contributions of labour and other non-financial contributions. The shortcomings of the approach in the assets for care situations is that the relief is centred around contributions that can be given a monetary value. ${ }^{71}$ This denies the context in which the arrangements are made, and the benefits that are no longer available to the older party.

\section{Some Suggestions for Law Reform}

It is a sadly recurring judicial experience to see that family relationships do deteriorate and become intolerable, and that the persons involved did not foresee that this might happen. ${ }^{72}$

To date, the response of Australian legislatures has been disappointing. Such arrangements were considered in the Older People and the Law inquiry in $2007^{73}$ resulting in a recommendation that the Standing Committee of Attorneys-General undertakes an investigation of legislation to regulate family agreements. ${ }^{74}$ Consideration was given to whether such a scheme should be implemented at the Commonwealth or at the State/ Territory level, the formalities required and the desirability of registration. It was further recommended that guidelines, model provisions and educational material be developed. ${ }^{75}$ All recommendations were accepted in principal but have not progressed at either Commonwealth or State level. And, despite recurring calls from older peoples advocacy organisations and legal representatives ${ }^{76}$ that the government act to introduce regulation of family accommodation arrangements, little has been done to advance these recommendations. ${ }^{77}$

70 [2014] QDC 150.

71 See, generally, Swettenham v Wild [2005] QCA 264.

72 Bennett v Horgan (unreported, NSWSC, 3 June 1994).

73 House of Representatives Standing Committee on Legal and Constitutional Affairs, Parliament of Australia, Inquiry into Older people and the Law - Final Report (2007).

74 Ibid, Recommendation 30.

75 Ibid, Recommendations 32 and 33.

76 For example, Seniors Rights Victoria and the Older Peoples Rights Service.

77 Recommendation 31 proposes that existing Family Dispute Resolution Services be enacted to resolve disputes concerning Family Agreements. The Government's Response for rejecting this recommendation is based on existing resolution services being defined solely within the domain of the Family Law Act 1975 (Cth). Thus any reform accordingly would involve legislative changes to that Act. We note however, that Recommendation 30 (which has been 'accepted in principal' by the Government's Response) includes investigation for establishing a provision, 'of a mechanism to enable the courts to dissolve family agreements in cases of dispute and grant appropriate relief to the parties involved'. 


\section{A Formalising Family Accommodation Arrangements}

Documenting, in a written agreement, a loving, caring or supportive personal relationship, for example, is probably anathema to many Australians. ${ }^{78}$

Many of the problems associated with family accommodation arrangements could be avoided if parties entered into a formal family agreement; a contract that sets out the contributions, rights and obligations of the parties including what will happen in the event that the agreements breaks down.

Unfortunately, such contracts are rarely considered by families, let alone actually entered into. Although agreements recording financial arrangements between spouses are now relatively commonplace, this is not the case with family accommodation arrangements. Case studies reveal that most people simply did not consider recording the agreement, let alone doing so formally. The expense of drawing up a legal document was a concern to some but the overriding reason for not travelling a legal path was that people simply did not expect anything to 'go wrong'. Indeed, in some cases where the issue was raised it caused friction along the lines of 'families don't sign contracts' and 'don't you trust me?'. Somewhat ironically, in some cases legal advice is obtained in order to transfer property or to review wills in the light of the family arrangement but the agreement itself was not formalised in writing.

Several draft agreements have been prepared and are available to the public including the Seniors Rights Victoria agreement. ${ }^{79}$ Unfortunately, the issue of awareness of the availability of the agreements, together with the concerns discussed in the preceding paragraph regarding family relationships, mean that such resources are likely to remain underutilised. Furthermore, although AA are performed routinely by many solicitors with a specialisation in elder law, many solicitors do not understand the potential pitfalls of these transactions. ${ }^{80}$

It is relevant here that Centrelink ${ }^{81}$ recognises 'Granny Flat Interests' (GFI) for the purpose of assessing an older person's right to social security payments. A GFI is created when an older person pays for the right to live in accommodation in a private residence for the duration of their life. This accommodation must be their principal home. ${ }^{82}$ An older person may 'pay' for a GFI via money or assets.

78 Brian Herd, 'Family Agreements: A collision between love and the law' (2002) 81 Australian Law Reform Commission Reform Journal 23.

79 Seniors Rights Victoria, Assets for care: a guide for lawyers to assist older clients at risk of elder abuse <http://www.seniorsrights.org.au/assetsforcare/wp-content/ uploads/Assets-for-Care.pdf $>$.

80 See, eg, recent research completed in Western Australia: Aviva Freilich, Pnina Levine, Ben Travia and Eileen Webb, Security of tenure for the ageing population in Western Australia: Does current housing legislation support Seniors' ongoing housing needs? (2014) <http://www.cotawa.org.au/wp-content/ uploads/2015/04/121975_Housing-Report-text.pdf>

81 The Department of Veterans Affairs also recognises GFIs.

82 Department of Human Services, Australian Government, Granny Flats - Features, Rights and Interests (17 March 2014) <http://www.humanservices.gov.au>. 
GFIs protect Centrelink benefits that may otherwise be lost if an older person sells their home. If deemed to be entering into a GFI (as defined) the older person will not be deprived of their pension. ${ }^{83}$ Entering into a GFI may affect older people's Centrelink benefits through the transfer of additional assets ${ }^{84}$ and/or a potential impact on rental assistance payments. So far as proof of existence of a GFI is concerned, a written agreement is not necessary ${ }^{85}$ and a written statement advising that the GFI arrangement has commenced is routinely accepted by Centrelink.

Clearly, many FAA will also fall within the classification of GFI and older people entering into an FAA should be mindful of the possible Centrelink consequences of entering into a FAA. Such arrangements may, however, be advantageous in that there is some, albeit often verbal, record of the arrangement should the arrangement deteriorate over time. Indeed, perhaps formalising GFI interests through Centrelink may be a method of ensuring that the arrangements are recorded in some detail.

\section{B Assuming That Parties Will Rarely Agree to Formalise the Arrangements, What is the Next Step?}

\section{Legislation Regulating Family Accommodation Arrangements}

The State, Territory and Commonwealth parliaments should cooperate to develop and implement legislation regulating formalities, content and use of family accommodation arrangements, and provide for adequate remedies in the event of the agreement's failure. Such legislation should define a family accommodation arrangement with such definition being broad enough to encompass informal arrangements.

To ease the process, the legislation could provide for a standard form agreement that was widely available ${ }^{86}$ and state that the standard form must be utilised. In the absence of a formal agreement the legislation should include a presumption that the agreement was reached as a result of undue influence and, unless the beneficiary can discharge the onus, the transaction will be set aside.

83 Ibid. The three circumstances are: (1) If they transfer their property's title to another person and retain a lifetime right to live in that home or in another home (provided the home was, or would have been, totally exempt from the asset test); (2) The person paid the cost of building the granny flat on someone else's property or converting another person's property to meet their needs and to establish a lifetime right to live there; or (3) If the person purchases property in another's name and establishes a lifetime right to live there.

84 If additional assets are transferred, Centrelink applies a test of 'reasonableness' to the transaction.

85 Department of Social Services, Australian Government, Accommodation Choices for Older Australians and their Families (2015) <http://www.nslhd.health. nsw.gov.au/Services/Carer/resourcesforcarers/Documents/accomodations\%20 choices\%20for\%20older\%20australians.pdf $>$.

86 As is the case in Australia with wills and enduring powers of attorney. 
The legislation could provide that legal advice must be obtained prior to entering into a family accommodation arrangement and that a certificate confirming the legal advice must be provided by the solicitor. This is a common occurrence in Australia when entering into certain small business contracts yet such a requirement is unnecessary when older people enter into significant transactions regarding their property. ${ }^{87}$

To avoid the vagaries of the presumption of advancement in relation to gifts from parent to child, any legislation governing family agreements should provide that such a presumption is to be disregarded. Finally, the legislation should provide for appropriate remedies and provide for penalties in the event of financial abuse.

\section{Amendment of the Relevant Real Property Statutes}

If specific legislation is not introduced, it may be possible to address the problem through real property law. Jurisdictions throughout Australia utilise the Torrens System of land registration. In summary, only certain interests can be registered on the title to the land and the registered owner's title is indefeasible unless certain exceptions to indefeasibility apply. ${ }^{88} \mathrm{~A}$ family accommodation arrangement is neither a registerable interest nor an exception to indefeasibility. In some cases such an interest can be protected by a caveat on the title but this is not a satisfactory long term solution. ${ }^{89}$

In our view, the relevant real property legislation could be amended to provide that a family accommodation arrangement is a registerable interest. Therefore, like a registered lease, mortgage or easement, anyone dealing with the land would have to be subject to the interests of the older person under the registered family accommodation arrangement. The problem with this proposition is, however, that like entering into formal family accommodation arrangements, many people may choose not to register citing issues such as inconvenience, expense and allegations of a lack of trust.

To counter this, family accommodation arrangements could be included in existing real property legislation as an exception to indefeasibility. Although in most cases such arrangements will give rise to an

$87 \quad$ For example, before entering into shopping mall leases and franchises, small business people must obtain certificates of legal and in some cases accounting advice.

88 Indefeasibility of title is: 'a convenient description of the immunity from attack by adverse claim to the land or interest in respect of which he is registered, which a registered proprietor enjoys. This concept is central in the system of registration. It does not involve that the registered proprietor is protected against any claim whatsoever; as will be seen later, there are provisions by which the entry on which he relies may be cancelled or corrected, or he may be exposed to claims in personam. These are matters not to be overlooked when a total description of his rights is required. But as registered proprietor, and while he remains as such, no adverse claim (except as specifically admitted) maybe brought against him': Frazer $v$ Walker [1967] 1 AC 569, 580. 
equitable interest, equitable interests are only good against the original parties to the agreement. Therefore, if the property was sold to a third party the purchaser would not be obliged to honour the agreement. For example, if an older person purchases land for, or contributes to, property for another (usually an adult child); the property is sold to a third party and that third party became registered, as things stand the older person would have no claim against the third party. The third party's title would be indefeasible, the older person would not have any interest in the land, no matter how significant his or her original contribution, and the only action available for the older person would be a private action against the child. Although this proposition would seem to undermine the principles of indefeasibility, it is not without some Australian precedent. For example, the list of exceptions to indefeasibility in the Victorian legislation have been held to extend to promises of accommodation for life. ${ }^{90}$

If such an approach was not palatable to the various legislatures, another possible solution could be that a family accommodation arrangement could be made the subject of a non-lapsing caveat. This is possible under existing legislation in certain circumstances. ${ }^{91}$ Again, this may not be ideal as the caveat procedure can be unwieldy, can impact upon even relatively routine transactions and issues of trust within families may arise.

\section{The Situation Remains Unchanged and the Courts Deal With Family Accommodation Arrangements}

If the situation remains unchanged it will still be up to the courts to consider family accommodation arrangements and the pitfalls discussed above. In such circumstances, the main issues are proof, presumptions and remedies.

In our view, courts should recognise a presumption of undue influence in significant parent to child transfers. The American State of Maine, for example, presumes undue influence where an older independent person transfers real estate or has undertaken a major transfer of personal property or money for less than full consideration. Further, the courts should disregard the presumption of advancement in relation to gifts from parent to child. Finally, and this is of particular relevance to the discussion above regarding constructive trusts, courts should avoid treating such transactions as joint ventures akin to a commercial transaction. Consideration needs to be given to the familial nature of the transaction, the expectations of the parties and the potentially serious consequences to the older person.

$90 \quad$ Calderone v Perpetual Trustees Victoria Ltd [2008] VSC 373.

91 For example, the Improper Dealings Caveat prevents the registration of any instruments or documents that normally need to be signed by the registered proprietor, including transfers of the land to another party. All owners must agree to the lodging of the caveat and its removal. Only a solicitor, not a settlement agent, is qualified to lodge such a caveat. 
Finally, as discussed, the remedies awarded to older people where family accommodation arrangements fail are often insufficient for them to start again and obtain new accommodation. Furthermore, the stress and expense of taking a matter to court would discourage many older people from proceeding.

\section{Concluding Comments}

Although we have examined the Australian law, these transactions are certainly not unique to Australia and promise to become increasingly problematic as populations age and the cost of home affordability rises.

There can be no doubt that the present state of the Australian law is unsatisfactory. Older, at times vulnerable, ${ }^{92}$ people are encouraged to enter into significant financial transaction involving what is usually their only asset; the family home. At present there is no compulsion to record the transaction and in most cases contract and real property law cannot assist. The result is that the older person must - if he or she can financially and/or emotionally litigate in such circumstances-rely on the vagaries of equitable doctrine. He or she must rebut historical presumptions that have not evolved to address contemporary family transactions, navigate courts that view family arrangements as akin to commercial enterprises and are unlikely to obtain a remedy that compensates the older person for their actual loss.

Furthermore, the interest in and will of Australian governments to address this issue seems to be wanting. Family accommodation arrangements were considered in the Older People and the Law inquiry in 2007. Recommendation 30 of the Committee Report stated:

[T] he Australian Government propose that the Standing Committee of Attorneys-General undertake an investigation of legislation to regulate family agreements. ${ }^{93}$

Consideration was given to whether such a scheme should be implemented at the Commonwealth or at the State/Territory level, the formalities required and the desirability of registration. The recommendation was accepted in principal.

Recommendations 32 and 33 called for guidelines, model provisions and educational material to be developed concerning Family Agreements. Again, this was accepted in principal. In 2010, The Older Peoples Rights Service recommended in the strongest terms that the State Government act to introduce regulation of inter alia FAA. Unfortunately, to date, little has been done to advance these recommendations. ${ }^{94}$

$92 \quad$ It should be emphasised that such vulnerability may not be due to an older person's constitutional vulnerabilities such as failing health but through situational vulnerability due to the family relationship.

93 House of Representatives Standing Committee on Legal and Constitutional Affairs, above $\mathrm{n} 73$.

94 Recommendation 31 proposed that existing Family Dispute Resolution Services be enacted to resolve disputes concerning Family Agreements. The Government's 
This article began with the tale of a father's anger at his son (innocently) making off with an inheritance prior to the parent's death. Leaving aside the availability of the King's wrath as a possible remedy, had Price Hal taken the riches knowing his father was alive, there is little difference between the issues that Henry IV would have had to navigate to retrieve his property and that awaiting an older person in an analogous situation today. A contemporary and appropriate legal response is imperative.

Response rejected this recommendation based on existing resolution services being defined solely within the domain of the Family Law Act 1975 (Cth). 